\title{
JUURNAL.RU
}

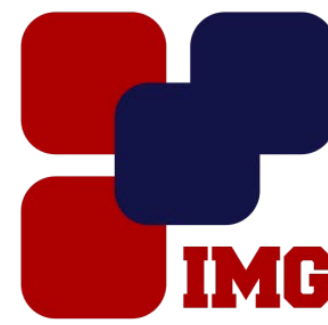

Iyanoy
MaNagement
GRoup

Каращенко В.В. «Южно-Российский государственный политехнический университет (НПИ) имени М.И. Платова» Шахтинский институт (филиал) ЮРГПУ (НПИ) им. М.И. Платова

Шахты, Россия

doi: 10.18411/lj-28-02-2017-2-05

idsp 000001:lj-28-02-2017-2-05

\section{Самостоятельность в разработке индивидуальных форм финансовой отчетности согласно МСФО}

\section{Аннотация}

В статье выявляется степень самостоятельности в разработке форм финансовой отчетности согласно МСФО и ПБУ. Сравнивается порядок детализации и оценки статей, приводятся минимальные линейные статьи отчета о финансовом положении.

Ключевые слова: МСФО, ПБУ, индивидуальные формы, финансовая отчетность, линейные статьи, детализация, самостоятельность.

В МСФО не содержится форм финансовой отчетности обязательных к применению. Индивидуальные формы отчетности организации разрабатывают самостоятельно с учетом требований, предъявляемых стандартами. В России организациям предоставлено право самостоятельно разрабатывать формы бухгалтерской отчетности, но при этом Минфин России рекомендует использовать регламентированные образцы форм и учитывать ограничения по составу, содержанию и методическим основам формирования отчетности. В ПБУ 4/99 определены подходы к раскрытию существенной информации, ориентированные на ее важность для заинтересованных пользователей.

Отчет о финансовом положении (бухгалтерский баланс) является основным отчетом в комплекте документов финансовой отчетности, как по МСФО, так и по ПБУ. Другие отчеты служат расшифровкой к статьям бухгалтерского баланса. Тем не менее, такие расшифровки являются настолько важными, что без них невозможно оценить финансовое положение организации, принять управленческое и финансовое решение, оценить эффективность управления.

В МСФО не предписывается строго регламентированная форма баланса, но есть требования к порядку представления статей и раскрытию информации. Названия минимальных линейных статей, приведенных в Стандарте (IAS 1 
«Представление финансовой отчетности»), не носят обязательного характера. Организации самостоятельно устанавливают названия статей, их порядок представления в отчетности, детализацию. Информация, подлежащая представлению в отчете о финансовом положении, должна включать как минимум следующие линейные статьи.

Таблищุа 1.

Условные названия линейных статей

\begin{tabular}{|c|c|}
\hline 1. Основные средства & $\begin{array}{c}10 . \text { Активы, предназначенные для продажи или } \\
\text { выбытия }\end{array}$ \\
\hline 2. Инвестиционная недвижимость & $\begin{array}{c}11 . \text { Неконтролируемая доля участи в собственном } \\
\text { капитале }\end{array}$ \\
\hline 3. Нематериальные активы & 12. Собственный капитал и резервный капитал \\
\hline 4. Финансовые активы & 13. Кредиторская задолженность \\
\hline 5. Инвестиции в долевом участии & 14. Финансовые обязательства \\
\hline 6. Биологические активы & 15. Резервы \\
\hline 7. Запасы & 16. Текущие налоговые обязательства \\
\hline 8. Дебиторская задолженность & $\begin{array}{c}17 . \text { Отложенные налоговые обязательства и } \\
\text { отложенные налоговые активы }\end{array}$ \\
\hline 9. Денежные средства и их эквиваленты & $\begin{array}{c}18 . \text { Обязательства по группам выбытия активов, } \\
\text { предназначенных для продажи }\end{array}$ \\
\hline
\end{tabular}

Порядок представления статей в отчетности и ее детализацию организации устанавливают самостоятельно. В МСФО нет предписания порядка, в котором статьи должны представляться в балансе. Порядок представления и названия статей могут разрабатываться в соответствии с характером организации и ее операций. Каждая статья должна раскрываться в балансе или в примечании к нему.

При разбивке статей на подклассы необходимо учитывать принцип существенности. Как минимум каждая статья должна разбиваться на подклассы по характеру и суммам кредиторской и дебиторской задолженности материнской, дочерних и других компаний. Например, для собственного капитала в балансе или в примечаниях к нему должна показываться следующая информация: количество акций, разрешенных к выпуску; количество выпущенных или полностью оплаченных акций, а также выпущенных, но не оплаченных полностью; номинальная стоимость акций; сверка количества акций в обращении в начале и конце года; права и привилегии по видам акций, ограничения и распределение дивидендов; количество акций, виды, принадлежащие материнской и дочерним компаниям; другая информация. Компании, не являющиеся акционерными обществами, должны представлять информацию, эквивалентную вышеназванным требованиям.

Активы и обязательства, отличающиеся по своему характеру, подлежат оценке на разной основе. Например, отдельные виды активов по подклассам могут оцениваться по первоначальной стоимости (фактической себестоимости) или восстановительной стоимости (стоимости замещения). Оценка по первоначальной стоимости является традиционной и преобладающей, но не единственной. МСФО признают равноправными и другие виды оценок. 
Использование различных основ оценки предполагает, что они различаются по своему характеру и таким образом должны представляться в качестве отдельных линейных статей. Запасы могут быть представлены в виде товаров, материалов, незавершенного производства или в виде единой статьи - «Запасы» (единая статья «Запасы» представлена укрупнено и российском формате баланса). Организация должна раскрывать в балансе или в примечании к нему дальнейшие подклассы каждой из представленных линейных статей, классифицированных в соответствии с операциями организации. Например, по видам товаров, материалов, сырья, полуфабрикатов, тары.

В заключении отметим следующее: IAS 1《Представление финансовой отчетности», не предписывает конкретный порядок или формат, в котором статьи должны представляться в бухгалтерском балансе. Статьи могут быть представлены в зависимости от изменения ликвидности или деления активов на краткосрочные и долгосрочные. Степени ликвидности не регламентируются в МСФО, классификация ликвидности лежит в сфере профессионального суждения. Выбранная форма отчета, названия линейных статей, порядок их отражения утверждается в учетной политике.

\section{Литература}

1. Ковалев, С.Г. Международные стандарты финансовой отчетности в примерах и задачах: Практическое пособие / С.Г Ковалев, Т.Н. Малькова. - М.: Финансы и статистика, 2006. - 296 с.

2. Перечень стандартов МСФО [Электронный ресурс]. - Режим доступа: http://www.nalog-nalog.ru> 